\title{
COMPARISON AMONG SOME SELECTION PROCEDURES TO PRODUCE THE NUCLEOLUS (BREEDER SEED) OF THE EGYPTIAN COTTON VARIETY GIZA 92 (GOSSYPIUM BARBADENSE L)
}

\author{
M.A.A. El-Dahan \\ Cotton Research Institute, Agricultural Research Center, Giza, \\ Egypt
}

\begin{abstract}
The main objective of this work was to compare between the selection methods of maintaining and renewing the breeder seeds of Giza 92 followed by the Department of Cotton Maintenance, Cotton Research Institute, A.R.C., and selection index procedures for the possibility of selection higher yielding plants with the same fiber properties of Giza 92. To form the new nucleolus (breeder seeds) two selection procedures were followed, the first was the procedure followed by the Department of Cotton Maintenance based on selection the best families representing the type of Giza 92 variety. The second was the procedure of classical selection index with different applications of selection intensity. Yield and yield components as well as fiber traits were evaluated for seven nucleolus, one from the traditional method and six from selection index method. Mean results showed that the means of the selected families were slightly differ from comparisons, which indicate the homogeneity between these families, also values of SE and C.V. \% were relatively low for all traits except for SCY and LCY confirming the homogeneity between these families and the influence of seed cotton yield (SCY) and lint cotton yield (LCY) by environmental factors. Heritability of the studied traits ranged from moderate $64.56 \%$ for yellowness (+b) to high $97.81 \%$ for uniformity index (UI \%). These results indicate the possibility to maintain the standard characters of Giza 92 variety by simple selection for these traits. Factor analysis showed that, three classes of independent factors were chosen based on Eigen value $>2$, which together compose $61.28 \%$ of total variation. Contribution of these three factors in total was $23.83,19.32$ and $18.13 \%$, respectively. Due to the relatively important of traits in each factor, factor 1 considered yield factor, factor 2 considered yield and fiber factor and factor 3 considered fiber factor. Which exhibit the importance to compare the selection index procedure in this work based on yield traits alone, fiber traits alone and all traits. Genotypic correlation revealed that selection for the direction of yield improvement can simultaneously maintain micronaire value $(\mathrm{MV})$ and yellowness $(+b)$ in the range of the variety standard. On the other hand, genotypic correlation between fiber strength (FS) which characterize G 92, was undesirable (negative) with fiber length at $2.5 \%$ Span length $(2.5 \% \mathrm{SL})$ and elongation (E\%.) and positive with micronaire value (MV), this mean special balance must be consider at the selection for these traits. Regarding to predicted gains, Application-3 (using yield and yield components with selected three families) presented the highest desirable
\end{abstract}


predicted gains for Boll weight (BW.) and Fiber length at 2.5\% Span length (2.5\%SL). The highest predicted gains for SCY and LCY were observed in Application-4 (using yield and yield components with selected seven families), because both seed and lint cotton yields exhibited greater magnitude of genetic variances across this application. Application-5 (using fiber traits with selected three families) presented the highest desirable predicted gains for seed index SI, lint index (LI), fiber strength (FS), micronaire value (MV) and brightness (Rd \%), and Application-6 (using fiber traits with selected seven families) for lint percentage ( $\mathrm{L} \%)$, uniformity index (UI\%), maturity ratio (MR) and yellowness $(+b)$. It conclude that using selection index procedure to produce breeder seeds in Giza 92 variety could significantly improve seed cotton yield and lint cotton yield maintaining in the same time the standard fiber properties.

Key words: Cotton, Giza 92, Selection, Nucleolus.

\section{INTRODUCTION}

Egyptian cotton is considered a peculiar type of cotton that is characterized by high quality, and gained a world-wide reputation as being of the highest lint quality among world cottons. Its fineness, strength and superior characteristics, have positioned its products as the world's finest. Most of Egyptian cotton varieties were produced by pedigree selection method. Both of pedigree selection and independent culling levels were used in maintenance and renewing Egyptian cotton varieties. Independent culling levels are a more common and practical procedure of selecting breeding families used by department of cotton maintenance. The primary problem with this procedure is that the breeder may eliminate an individual or family that is excellent in one or more traits due to poor performance in another. This considers a big problem in cotton selection due to the increasing of traits number under this type of selection, where the optimum trait number for this selection type ranges from two to three traits.

The main task of the department of Egyptian cotton varieties maintenance is to keep the cotton variety out of the genetic changes "deterioration" so that the standard characters of such variety will be stable for a long time. Also, providing the cotton area for each variety annually by new waves of genetically pure seed stocks. The breeder mainly concerned on maintenance of the known fiber properties of a variety rather than yield and its components. Selection index techniques can be used to improve several traits simultaneously, depending mainly upon genetic parameters and heritability (Smith, H.F. 1936, Manning, H.L. 1956, El-Kilany, M.A. 1976 and Abo ElZahab, A.A., M.A. El-Kilany 1979). Employing selection index techniques were mostly better than single phenotypic trait selection. Furthermore, selection index is possible to predict the difference 
between the mean of a proportion selected by truncation and the mean of the original population for each character. This "expected response" may be used to evaluate beforehand the consequences of several alternative selection procedures. "Observed response" implies that the selection has already been done (Pesek and Baker, 1970). In connection with the computation of genetic variances and means, it is of fundamental importance to establish estimates of other genetic parameters, such as the coefficient of heritability and genetic variation, index of variation and genetic correlations to predict gains, so the viability of determined improvement program can be evaluated and the most efficient selection strategy can be adopted (Vencovsky, 1969).

Quantitative trait like yield being polygenic is a total sum of genetic illustration of all the yield components (Larik et al., 1997) and is significantly affected by environmental factors (Khan et al., 2007). The overall performance of a genotype may vary due to changes in environment and the higher the heritability, the simpler the selection process and greater the response to selection (Larik et al., 1997 \& 2000; Soomro et al., 2008). In addition, a thorough knowledge about the mean performance, extent of relationship and correlation of yield with various agronomic characters is indispensable for breeder to tackle the problem of yield increase successfully. The correlation analysis also reflects the correlated response of a particular character with its counterpart and also provides a good index to predict the corresponding change which occurs in one character at the expanse of the proportionate change in the other (Khan, 2003; Ahmad et al., 2008). Dhivya et al., (2014) observed that high genetic advance, genetic gain and heritability were recorded for single plant yield, seed index, micronaire value and $2.5 \%$ span length indicated that selection can be resorted for the improvement of these characters in the future crop improvement programs.

The main objective of this work was to compare between the selection method of maintaining and renewing the breeder seeds of Giza 92 followed by the department of cotton maintenance, Cotton Research Institute, A.R.C., and another selection index procedures depends mainly on genetic parameters for the possibility of selection elite high yielding plants characterized by the same fiber properties of Giza 92.

\section{Plant Material:}

\section{MATERIALS AND METHODS}

Giza 92 cotton variety is a commercial Egyptian cotton cultivar (G. barabadense L.) cultivated at north delta region and classified extra-long stable with a stable length $(34.5-35 \mathrm{~mm})$ and represents the highest level of fiber strength in the world (50-53 g/tex). This variety 
was derived by the pedigree selection method from the cross between Giza 84 x (Giza 74 x Giza 68) and released commercially in 2011. The present study was carried out at Sakha Agricultural Research Station, Cotton Res. Inst., during three seasons of 2014 -2016. The basic materials for this study were seeds of 31 type single plants selected from the breeding nursery of renewal and maintenance of Giza 92 of 2013 season.

In 2014 season, the selfed seeds of the progenies of the 31 selected type plants were grown in number of rows as the amount of seed allowed conveniently named increase line $A$, as well as the natural pollinated seeds of same 31 selected type plants were grown adjacent progeny three rows to be increased for using it in yield trial in the next year. Accordingly the field and laboratory tests of yield and its components and fiber properties, 17 families were selected from increase $\mathrm{A}$.

In 2015 season, the selected seeds of the 17 families were grown in increase B. A yield trial included the 17 selected families as well as the three latest strains of Giza 92 were used as controls. The design of yield trail was a randomized complete blocks design with four replications. The twenty families were evaluated for yield, its components and fiber properties. To form the new nucleolus (breeder seed) two selection procedures were followed, the first is the procedure followed by the department of cotton maintenance based on selection the best families representing the type of Giza 92 variety from increase $B$ and the second was the procedure of classical selection index with different types of selection intensity, table 1 shows the breeder seed types released in this work. The selected families from each selection procedure (Table 1), were carefully massed together to form the different type of the new nucleolus.

In 2016 season, the different nucleolus (breeder seeds) raised from the previous season were compared in randomized complete block design trail to detect the differences between the traditional selection procedure followed by the department of cotton maintenance and the classical selection index.

\section{Selection Procedures:}

Two selection approaches were implemented in this research (Table 1);

1. The traditional selection procedure, followed by the department of cotton maintenance which based on the selection of the best families representing Giza 92 variety taking as the reference the three latest strains of Giza 92. This procedure depending mainly on the experience of the breeders and the visual evaluation of the 
seed type; and do not take in account any genetic parameters. Seven families were selected by this procedure.

2. Classical selection index procedure with three and seven families as $17.6 \%$ and $41.2 \%$ selection intensity, respectively which enable the breeder to make balanced selection decisions taking into account the consideration of the several traits with varying degrees of agronomic and economic importance and the relevance of yield and fiber traits of each family to identify the families that is most profitable for their particular behavior. Table 1, showed the families derived from each application procedure.

Table 1: Breeder seed applications

\begin{tabular}{|c|c|c|c|}
\hline Application & Procedure & $\begin{array}{l}\text { Selection } \\
\text { intensity }\end{array}$ & $\begin{array}{l}\text { Selected } \\
\text { families }\end{array}$ \\
\hline 1 & $\begin{array}{l}\text { Classical selection index using all } \\
\text { traits. }\end{array}$ & $\begin{array}{l}\text { Three families } \\
(17.6 \%)\end{array}$ & $6-12-14$ \\
\hline 2 & $\begin{array}{l}\text { Classical selection index using all } \\
\text { traits. }\end{array}$ & $\begin{array}{c}\text { Seven families } \\
(41.2 \%)\end{array}$ & $\begin{array}{l}3-4-6-7-10-12- \\
14\end{array}$ \\
\hline 3 & $\begin{array}{l}\text { Classical selection index using } \\
\text { yield and yield components. }\end{array}$ & $\begin{array}{l}\text { Three families } \\
(17.6 \%)\end{array}$ & $3-5-14$ \\
\hline 4 & $\begin{array}{l}\text { Classical selection index using } \\
\text { yield and yield components. }\end{array}$ & $\begin{array}{c}\text { Seven families } \\
(41.2 \%)\end{array}$ & $\begin{array}{l}1-3-5-6-8-13- \\
14\end{array}$ \\
\hline 5 & $\begin{array}{l}\text { Classical selection index using } \\
\text { fiber properties. }\end{array}$ & $\begin{array}{c}\text { Three families } \\
(17.6 \%)\end{array}$ & $3-4-14$ \\
\hline 6 & $\begin{array}{l}\text { Classical selection index using } \\
\text { fiber properties. }\end{array}$ & $\begin{array}{l}\text { Seven families } \\
(41.2 \%)\end{array}$ & $\begin{array}{l}1-2-3-4-7-13- \\
14\end{array}$ \\
\hline 7 & $\begin{array}{l}\text { procedure followed by the } \\
\text { department of cotton maintenance } \\
\text { (G92/2016 nucleolus) }\end{array}$ & $\begin{array}{l}\text { Seven families } \\
\quad(41.2 \%)\end{array}$ & $\begin{array}{l}2-5-7-12-13- \\
15-17\end{array}$ \\
\hline
\end{tabular}

\section{Studied traits:}

Data of the following traits were recorded:

Yield and yield component traits are:

1. Seed cotton yield (SCY) in K/F.

2. Lint cotton yield (LCY) in K/F.

3. Lint percentage $(L \%)$.

4. Boll weight (BW.) in $\mathrm{g}$.

5. Seed index (SI) in $\mathrm{g}$.

6. Lint index (LI) in $\mathrm{g}$.

Fiber properties were:

1. Fiber length at $2.5 \%$ Span length $(2.5 \% \mathrm{SL})$ in $\mathrm{mm}$.

2. Uniformity index (UI\%).

3. Fiber strength (FS) ( $g /$ tex).

4. Elongation ( $\mathrm{E} \%$.).

5. Micronaire value (MV).

6. Maturity ratio (MR)

7. Brightness (Rd \%).

8. Yellowness $(+b)$. 


\section{Statistical Analysis}

The following statistical analysis was carried out for the 17 families of increase B during 2015 season. Phenotypic (PCV) coefficient of variation were estimated using the formula developed by Burton (1952). Heritability in broad sense $\left(\mathrm{h}^{2}\right.$ b) was calculated according to Walker (1960). Factor analysis of the contributed characters were expressed with Eigen value and manifested in Eigen vector for all the studied characters in each factor (Hair et al., 1987). All these computation were performed using SPSS (1995) computer procedure. Genotypic correlation coefficients between studied traits were estimated as outlined by Miller et al., (1958), and Dewey and Lu (1959).

Classical selection index ( $\mathrm{SH}$-index) was calculated from the formula of (Smith, 1936 ; Hazel, 1943):

$\mathrm{SH}$-index $=\mathrm{b}_{1} \mathrm{X}_{1}+\mathrm{b}_{2} \mathrm{X}_{2}+\ldots . .+\mathrm{bnXn}$

The appropriate index weights (b's) were calculated from the following formula postulated by Smith (1936) and Hazel(1943):

$(\mathrm{b})=(\mathrm{P})^{-1} \cdot(\mathrm{G}) \cdot(\mathrm{a})$

Where:

(b) $=$ Vector of relative index coefficients,

$(P)^{-1}=$ Inverse phenotypic variance-covariance matrix,

(G) = Genotypic variance-covariance matrix,

(a) $=$ Vector of relative economic values on the basis of equally

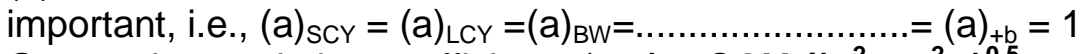

Genotypic correlation coefficients $\left.\left(r_{\text {gxy }}\right)=\operatorname{COV}_{\mathrm{g}} /\left(\sigma_{\mathrm{gx}}^{2} \sigma_{\mathrm{gy}}\right)^{2}\right)^{0.5}$

$\mathbf{C O V}_{\mathrm{g}}=$ Genotypic covariance between variable $\mathrm{x}$ and $\mathrm{y}$

$\boldsymbol{\sigma}_{\mathrm{gx}}{ }^{2}$ and $\boldsymbol{\sigma}_{\mathrm{gy}}{ }^{2}$ are genotypic variance for $\mathrm{x}$ and $\mathrm{y}$ variables respectively

\section{RESULTS AND DISCUSSION}

\section{Means, standard error, coefficients of variation and heritability}

Mean values of yield, yield component and fiber properties of the seventeen families selected from increase $A$, are presented in table 2. Mean results showed that the means of the selected families were slightly differ from comparisons, which indicate the homogeneity between these families, also values of SE and CV \% were relatively low for all traits except for SCY and LCY confirming the homogeneity between these families and the influence of SCY and LCY by environmental factors. Phenotypic coefficient of variation (PCV) of the basic materials of this work was high as $39.41 \%$ for SCY and $43.75 \%$ for LCY compared to quality traits $(10.48 \%, 5.33 \%$ and $1.11 \%$ for $2.5 \% \mathrm{SL}, \mathrm{MV}$ and MR, respectively). These results confirm the concept that long times of artificial selfing of Giza 92 plants in the breeding nursery resulted in a mixture of homozygous families similar to great 
extent in fiber properties and differ in yielding ability, and by selection become "pure line". Numerous studies have been published in agreement with these results, e.g., Kapoor and Kaushik (2003), Srour et al. (2010) and Ramadan et al. (2014). Knowledge of heritability is important as it indicates the possibility and extent to which improvement can be brought through selection. Heritability of the studied traits (Table 2$)$ ranged from moderate to high $(64.56 \%$ for +b to $97.81 \%$ for $\mathrm{UI} \%$ ). These results indicate the possibility to maintain the standard characters of Giza 92 variety by simple selection for these traits.

Table 2: Means of yield, yield components and fiber properties of the 17 selected families (increase B), phenotypic coefficient of variation (PCV $\%)$ and heritability in broad sense $\left(\mathrm{h}_{\mathrm{b}}^{2} \%\right)$, for the studied characters

\begin{tabular}{|c|c|c|c|c|c|c|c|c|c|c|c|c|c|c|}
\hline 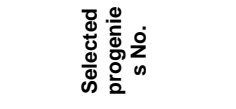 & 己ુ心 & 己产 & $\stackrel{5}{\circ}$ & $\begin{array}{l}\text { क्र } \\
\text { 3े }\end{array}$ & क्ర & $\begin{array}{l}\text { क्ञ } \\
\text { ప }\end{array}$ & 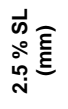 & $\stackrel{\circ}{5}$ & 战离 & ن̊ & $\mathbf{z}$ & $\frac{\tilde{a}}{\Sigma}$ & $\stackrel{\circ}{\check{c}}$ & $\stackrel{9}{+}$ \\
\hline 1 & 6.2 & 7.2 & 36.7 & 2.8 & 11.3 & 6.6 & 34.1 & 87.1 & 49.6 & 6.3 & 3.7 & 0.94 & 78.9 & 8.8 \\
\hline 2 & 6.8 & 7.7 & 35.9 & 2.7 & 11.4 & 6.4 & 35.4 & 87.4 & 48.8 & 6.2 & 3.8 & 0.94 & 79.7 & 8.2 \\
\hline 3 & 8.0 & 8.9 & 35.4 & 2.8 & 11.4 & 6.2 & 34.2 & 87.5 & 48.9 & 6.4 & 3.5 & 0.93 & 80.0 & 8.4 \\
\hline 4 & 6.6 & 7.6 & 36.5 & 2.8 & 11.2 & 6.4 & 35.2 & 86.5 & 48.4 & 6.6 & 3.5 & 0.92 & 80.2 & 8.5 \\
\hline 5 & 7.8 & 8.9 & 36.5 & 3.0 & 10.8 & 6.2 & 36.3 & 86.4 & 46.3 & 6.3 & 3.6 & 0.91 & 79.0 & 8.4 \\
\hline 6 & 8.3 & 9.4 & 35.8 & 2.8 & 11.2 & 6.3 & 34.3 & 85.5 & 46.5 & 6.6 & 3.7 & 0.94 & 78.7 & 8.4 \\
\hline 7 & 8.1 & 9.5 & 37.4 & 2.9 & 10.6 & 6.3 & 35.2 & 87.4 & 46.1 & 6.8 & 3.6 & 0.94 & 79.1 & 8.0 \\
\hline 8 & 8.5 & 9.8 & 36.9 & 3.0 & 11.2 & 6.6 & 34.0 & 85.0 & 46.6 & 6.4 & 3.6 & 0.92 & 78.8 & 8.3 \\
\hline 9 & 5.1 & 5.7 & 35.3 & 2.8 & 10.9 & 6.0 & 34.5 & 83.5 & 45.8 & 6.8 & 3.6 & 0.92 & 78.8 & 8.8 \\
\hline 10 & 6.8 & 7.8 & 36.3 & 2.8 & 10.8 & 6.1 & 34.5 & 85.9 & 47.9 & 6.3 & 3.8 & 0.93 & 79.5 & 8.1 \\
\hline 11 & 6.6 & 7.6 & 36.6 & 2.8 & 10.7 & 6.2 & 34.6 & 84.7 & 49.5 & 6.3 & 3.7 & 0.94 & 77.8 & 8.3 \\
\hline 12 & 5.5 & 6.4 & 36.2 & 2.8 & 10.8 & 6.1 & 34.9 & 83.9 & 46.5 & 6.8 & 3.7 & 0.92 & 78.4 & 8.4 \\
\hline 13 & 7.6 & 8.7 & 36.6 & 2.9 & 10.4 & 6.0 & 34.5 & 88.3 & 48.8 & 6.8 & 3.5 & 0.93 & 79.1 & 7.8 \\
\hline 14 & 6.7 & 7.9 & 37.4 & 3.0 & 10.8 & 6.4 & 34.4 & 87.7 & 49.1 & 6.3 & 3.5 & 0.94 & 78.3 & 8.2 \\
\hline 15 & 5.4 & 5.9 & 34.7 & 3.0 & 10.7 & 5.7 & 34.2 & 87.2 & 48.9 & 6.8 & 3.7 & 0.94 & 78.6 & 8.0 \\
\hline 16 & 7.0 & 8.0 & 36.7 & 2.8 & 10.8 & 6.3 & 35.5 & 85.7 & 45.1 & 6.6 & 3.5 & 0.91 & 79.0 & 8.4 \\
\hline 17 & 6.0 & 6.8 & 36.3 & 2.7 & 11.1 & 6.4 & 34.5 & 87.1 & 46.8 & 6.8 & 3.6 & 0.93 & 77.9 & 8.4 \\
\hline $\begin{array}{l}\text { Mean of selected } \\
\text { families }\end{array}$ & 6.9 & 7.9 & 36.3 & 2.8 & 11.0 & 6.3 & 34.7 & 86.3 & 47.6 & 6.5 & 3.6 & 0.93 & 78.9 & 8.3 \\
\hline $\begin{array}{l}\text { Mean of comparisons } \\
\text { (control) }\end{array}$ & 6.8 & 7.8 & 36.6 & 2.8 & 10.6 & 6.1 & 34.2 & 87.5 & 45.5 & 6.7 & 3.6 & 0.9 & 75.5 & 8.5 \\
\hline SE & 0.17 & 0.20 & 0.12 & 0.02 & 0.05 & 0.04 & 0.10 & 0.19 & 0.21 & 0.04 & 0.02 & 0.00 & 0.11 & 0.05 \\
\hline CV \% & 17.5 & 17.7 & 2.4 & 4.4 & 3.2 & 4.4 & 2.1 & 1.6 & 3.1 & 4.2 & 4.1 & 1.7 & 1.0 & 4.3 \\
\hline PCV\% & $\begin{array}{c}39.4 \\
1 \\
\end{array}$ & $\begin{array}{c}43.7 \\
5\end{array}$ & $\begin{array}{c}11.7 \\
6 \\
\end{array}$ & 5.91 & 9.22 & 8.67 & $\begin{array}{c}10.4 \\
8 \\
\end{array}$ & $\begin{array}{c}14.8 \\
6 \\
\end{array}$ & $\begin{array}{c}21.0 \\
5\end{array}$ & 9.07 & 5.33 & 1.11 & 7.41 & 8.84 \\
\hline $\mathbf{h}_{\mathrm{b}}^{2} \%$ & 81.5 & 83.9 & 81.8 & 69.0 & 86.0 & 75.4 & 80.2 & 97.8 & 95.7 & 75.8 & 70.5 & 65.9 & 91.3 & 64.6 \\
\hline
\end{tabular}




\section{Factor Analysis:}

In order to identify vital components that contribute to total variation, factor analysis was conducted. Table 3 shows total variance of each factor in percentage, which shows its importance in interpretation of total variation of data. Therefore, the contribution of each trait according to other traits is obtained. Three classes of independent factors were chosen based on Eigen value $>2$, which together compose $61.28 \%$ of total variation. Contribution of these three factors in total was $23.83,19.32$ and $18.13 \%$ respectively.

A principal factor matrix after Varimax rotation (Kaiser Normalization method, 1958) for these three factors given in Table.4 To interpret the results, only those factors loading having greater values are considered. Factor 1 , which account for about $23.83 \%$ of the variation consists of SCY, LCY, L\%, and BW. The suggested name for this factor is yield factor due to the importance of these traits in this factor. Factor 2, accounted for $19.32 \%$ of the variation consisted of BW, SI, $\mathrm{LI}$ and $+\mathrm{b}$ this factor can be also named yield and fiber factor. The third factor counted for about $18.13 \%$ of variation and consisted of $2.5 \%$ SL, UR\%, FS and MR this factor can be named as fiber factor. Factor analysis exhibited the rule of yield and fiber traits independently and together confirming the importance of these traits in the total variance. These results exhibit the importance to compare the selection index procedures in this work based on yield traits alone, fiber traits alone and all traits together, to detect the most suitable families included in each formed nucleolus.

Table 3: Eigen value, specific variance value and accumulative percentage variance for 14 factors

\begin{tabular}{|c|c|c|c|}
\hline Factors & Eigen value & Variation & Cumulative \\
\hline 1 & 3.34 & 23.83 & 23.83 \\
\hline 2 & 2.70 & 19.32 & 43.15 \\
\hline 3 & 2.54 & 18.13 & 61.28 \\
\hline 4 & 1.44 & 10.27 & 71.55 \\
\hline 5 & 1.12 & 8.00 & 79.55 \\
\hline 6 & 1.03 & 7.33 & 86.88 \\
\hline 8 & 0.78 & 5.57 & 92.45 \\
\hline 9 & 0.40 & 2.82 & 95.27 \\
\hline 10 & 0.28 & 1.98 & 97.25 \\
\hline 11 & 0.20 & 1.42 & 98.67 \\
\hline 13 & 0.10 & 0.69 & 99.36 \\
\hline 14 & 0.08 & 0.60 & 99.96 \\
\hline & 0.01 & 0.04 & 100.00 \\
\hline
\end{tabular}


Table 4: Rotated factor loadings and communalities for the first three factors

\begin{tabular}{|c|c|c|c|}
\hline Trait & Factor 1 & Factor 2 & Factor 3 \\
\hline SCY (K/F) & 0.88 & -0.10 & -0.02 \\
\hline LCY (K/F) & 0.91 & -0.12 & -0.04 \\
\hline L\% & 0.67 & -0.12 & -0.14 \\
\hline BW (g) & 0.64 & 0.61 & -0.01 \\
\hline SI (g) & 0.18 & -0.71 & 0.01 \\
\hline II (g) & 0.18 & 0.87 & 0.20 \\
\hline $2.5 \%$ SL (mm) & 0.24 & -0.08 & -0.54 \\
\hline Ul\% & 0.44 & -0.32 & 0.55 \\
\hline FS (q/tex) & -0.01 & 0.02 & 0.87 \\
\hline E\% & -0.45 & -0.44 & -0.37 \\
\hline MV & -0.36 & 0.29 & 0.37 \\
\hline MR & 0.04 & -0.08 & 0.88 \\
\hline Rd\% & 0.37 & 0.21 & 0.04 \\
\hline +b & -0.22 & 0.78 & -0.33 \\
\hline
\end{tabular}

\section{Genotypic correlation coefficients:}

The results of genotypic correlation coefficient (Table 5) revealed significant positive genotypic correlation coefficients were existed between most of yield traits except between SI and L\% with $\mathrm{BW}$. However MV and $+\mathrm{b}$ showed negative (desirable) correlation with most of yield traits except between MV and $\mathrm{SI}$ and between $+\mathrm{b}$ and $\mathrm{SI}$ and LI similar results were obtained by El-Lawendey et al. (2008), ElLawendey et al. (2011) and El-Lawendey and El-Dahan, (2012). These results revealed that selection for the direction of yield improvement can simultaneously maintain fiber finance and color in the range of the variety standard. On the other hand genotypic correlation between strength (FS) which characterize G 92, was undesirable (negative) with fiber length $(2.5 \% \mathrm{SL})$ and elongation (E\%) and positive with fiber fineness (MV), this mean special balance must be consider at the selection for these traits.

Table 5: Estimates of genotypic correlation coefficients $\left(r_{g}\right)$ between all pairs of studied traits

\begin{tabular}{|c|c|c|c|c|c|c|c|c|c|c|c|c|c|}
\hline Cha & $\begin{array}{l}\text { SCY } \\
(K / F)\end{array}$ & $\begin{array}{l}\text { LCY } \\
\text { (K/F) }\end{array}$ & L\% & BW (g) & $\begin{array}{l}\text { SI } \\
\text { (g) }\end{array}$ & LI (g) & $\begin{array}{c}2.5 \% \\
\mathrm{SL} \\
(\mathrm{mm})\end{array}$ & Ul\% & $\underset{(\mathrm{g} / \mathrm{tex})}{\mathbf{F S}}$ & E\% & MV & MR & Rd\% \\
\hline $\operatorname{LCY}(\mathrm{K} / \mathrm{F})$ & $0.99^{\star \star}$ & & & & & & & & & & & & \\
\hline L\% (K/F) & $0.60^{* *}$ & $0.68^{* *}$ & & & & & & & & & & & \\
\hline BW (g) & $0.38^{\star}$ & $0.40^{*}$ & $0.33^{*}$ & & & & & & & & & & \\
\hline SI (g) & 0.18 & 0.13 & $-0.29^{*}$ & $-0.60^{\star *}$ & & & & & & & & & \\
\hline LI (g) & $0.67^{\star *}$ & $0.68^{\star *}$ & $0.60^{* *}$ & -0.19 & $0.59^{*}$ & & & & & & & & \\
\hline $\begin{array}{l}\begin{array}{l}2.5 \% \mathrm{SL} \\
(\mathrm{mm})\end{array} \\
\end{array}$ & 0.16 & 0.19 & $0.29^{*}$ & 0.15 & -0.21 & 0.04 & & & & & & & \\
\hline UI\% & $0.30^{*}$ & $0.30^{*}$ & 0.20 & 0.17 & 0.03 & 0.22 & 0.01 & & & & & & \\
\hline FS (g/tex) & -0.17 & -0.18 & -0.12 & -0.18 & 0.16 & 0.02 & $-0.45^{\star}$ & $0.50^{\star}$ & & & & & \\
\hline $\mathrm{E} \%$ & $-0.37^{*}$ & $-0.36^{*}$ & -0.23 & 0.05 & $-0.53^{*}$ & $-0.64^{* *}$ & -0.14 & -0.13 & $-0.47^{\star}$ & & & & \\
\hline MV & $-0.26^{*}$ & $-0.34^{*}$ & $-0.92^{* *}$ & $-0.66^{\star *}$ & $0.23^{\star}$ & $-0.66^{\star *}$ & $-0.39^{*}$ & $-0.42^{*}$ & $0.35^{*}$ & $-0.49^{*}$ & & & \\
\hline MR & 0.14 & 0.10 & -0.21 & -0.17 & $0.32^{\star}$ & 0.08 & $-0.99^{\star *}$ & $0.78^{\star \star}$ & $0.99^{* *}$ & -0.18 & $0.48^{\star}$ & & \\
\hline $\mathbf{R d} \%$ & $0.45^{*}$ & $0.38^{*}$ & $-0.29^{*}$ & $-0.25^{\star}$ & $0.43^{*}$ & 0.05 & $0.25^{*}$ & $0.33^{*}$ & 0.09 & $-0.28^{*}$ & $-0.51^{*}$ & $-0.46^{*}$ & \\
\hline
\end{tabular}




\begin{tabular}{|l|c|c|c|c|c|c|c|c|c|c|c|c|c|}
\hline$+\mathbf{b}$ & $-0.56^{*}$ & $-0.53^{*}$ & -0.05 & $-0.68^{* *}$ & $0.90^{* *}$ & $0.76^{* *}$ & -0.08 & $-0.70^{* *}$ & $-0.29^{*}$ & $-0.23^{*}$ & 0.17 & $-0.43^{*}$ & $0.24^{*}$ \\
\hline
\end{tabular}
*and ** significant at the 0.05 and 0.01 levels of probability, respectively.

\section{Predicted gains from classical selection index for the different six nucleolus applications.}

Regarding to predicted gains from classical selection index for the six nucleolus applications (Table 6), the results showed that the lowest predicted gains for all studied traits were found when using Application-1(using all traits with selected three families). Since, positive/negative (+/-) genotypic correlations between most pairs of studied traits would lead to less response of total predicted gains. Application-3 (using yield and yield components with selected three families) presented the highest desirable predicted gains for BW and $2.5 \%$ SL. The highest predicted gains for SCY and LCY were observed in Application-4 (using yield and yield components with selected seven families), because both seed and lint cotton yields exhibited greater magnitude of variances across this application. Also, this may be attributed to coefficient of genetic correlations that showed strongly and positively correlated for SCY with LCY. Application-5 presented the highest desirable predicted gains for SI, LI, FS, MV and Rd\%, and Application- 6 for $\mathrm{L} \%, \mathrm{Ul} \%, \mathrm{MR} \%$ and $+\mathrm{b}$. these two applications based on classical selection index using only fiber traits with three and seven families as selection intensity. These results indicate that to maintain the range of the standard characters for Giza 92 variety, selection index could be used for yield traits group and for fiber traits group. It is not recommended to use both trait groups together in selection index.

\section{Analysis of variance and means of the different six nucleolus applications:}

Mean square of the studied traits (Table 7) showed that no significant difference between nucleolus application, except for SCY, $\mathrm{LCY}, \mathrm{SI}$ and $\mathrm{Rd} \%$, these traits could be the most affected by the environmental conditions. Means of the studied traits for the six nucleolus applications for SCY and LCY (Table 8), showed that selection for yield traits (Application-3 and Application-4) was significantly better than selection for fiber traits (Application-5 and Application-6) and both types were better than the traditional method carried out by the department of cotton maintenance (Application-7). However the total mean of the studied nucleolus applications for all traits did not differ greatly with the total mean of the basic increase B population mean confirming the genetic homogeneity of Giza 92 material across progenies. This may be due to the pedigree selection method used to develop Giza 92 materials during breeding and maintenance period ( $>15$ years) was exhausted the variations due to 
major genes effects. However minor genes have too small effects to be individually distinguished and segregation occurs at a large number of loci affecting a trait. Thus, the gene frequency changes caused by selection pressure exerted by the breeder as using selected three families in this work, and loss of heterozygosity (due to segregation of heterozygotes remaining even in the most highly bred varieties), could create some genetic modifications which consider the main reason for off-types plants appearance in the program. For these reasons continues selfing and selection procedures carried out every season consider essential in maintaining program to maintain genetic purity and eliminate any off-type plants from Giza 92 breeding population.

Table 6: Predicted gains (PG\%) from selection by using classical selection index (SH-index) for each application of breeder seed

\begin{tabular}{|c|c|c|c|c|c|c|c|}
\hline \multirow{2}{*}{ Trait } & \multirow{2}{*}{$\begin{array}{l}\text { Predicted } \\
\text { gains }\end{array}$} & \multicolumn{6}{|c|}{ Breeder seed applications } \\
\hline & & Application-1 & Application-2 & Application- 3 & Application- 4 & Application- 5 & Application- 6 \\
\hline \multirow{2}{*}{$\operatorname{SCY}(K / F)$} & PG & -0.004 & 0.235 & 0.491 & 0.562 & 0.186 & 0.215 \\
\hline & PG\% & -0.050 & 3.40 & 7.120 & 8.150 & 2.700 & 3.110 \\
\hline \multirow{2}{*}{$\operatorname{LCY}(\mathrm{K} / \mathrm{F})$} & $P G$ & 0.017 & 0.291 & 0.581 & 0.679 & 0.222 & 0.290 \\
\hline & PG\% & 0.210 & 3.68 & 7.360 & 8.590 & 2.810 & 3.670 \\
\hline \multirow[b]{2}{*}{ L\% } & $P G$ & 0.139 & 0.09 & 0.095 & 0.137 & 0.101 & 0.204 \\
\hline & PG\% & 0.380 & 0.26 & 0.260 & 0.380 & 0.280 & 0.560 \\
\hline \multirow{2}{*}{ BW (g) } & $P G$ & 0.026 & 0.00 & 0.065 & 0.029 & 0.015 & 0.081 \\
\hline & PG\% & 0.910 & 0.08 & 2.270 & 1.000 & 0.510 & 1.290 \\
\hline \multirow{2}{*}{ SI (g) } & $P G$ & -0.021 & 0.02 & 0.022 & 0.056 & 0.146 & -0.002 \\
\hline & PG\% & -0.190 & 0.18 & 0.200 & 0.510 & 1.330 & -0.060 \\
\hline \multirow{2}{*}{ LI (g) } & PG & 0.022 & 0.03 & 0.032 & 0.062 & 0.100 & 0.057 \\
\hline & PG\% & 0.350 & 0.51 & 0.520 & 0.990 & 1.600 & 0.520 \\
\hline \multirow{2}{*}{$\begin{array}{c}2.5 \% \mathrm{SL} \\
(\mathrm{mm})\end{array}$} & $P G$ & -0.144 & -0.05 & 0.203 & -0.135 & -0.107 & -0.011 \\
\hline & PG\% & -0.420 & -0.14 & 0.580 & -0.390 & -0.310 & -0.030 \\
\hline \multirow{2}{*}{ UI\% } & $P G$ & -0.563 & 0.05 & 0.888 & 0.494 & 0.904 & 1.088 \\
\hline & PG\% & -0.650 & 0.06 & 1.030 & 0.570 & 1.050 & 1.260 \\
\hline \multirow{2}{*}{ FS (g/tex) } & $P G$ & -0.260 & -0.01 & 0.442 & 0.326 & 1.102 & 0.858 \\
\hline & PG\% & -0.550 & -0.02 & 0.930 & 0.680 & 2.310 & 1.800 \\
\hline \multirow{2}{*}{$\mathrm{E} \%$} & $P G$ & 0.036 & 0.01 & -0.154 & -0.067 & -0.066 & -0.029 \\
\hline & PG\% & 0.550 & 0.13 & -2.370 & -1.040 & -1.010 & -0.450 \\
\hline \multirow{2}{*}{ MV } & PG & 0.022 & 0.00 & -0.055 & -0.019 & -0.072 & -0.022 \\
\hline & PG\% & 0.610 & -0.06 & -1.530 & -0.540 & -1.980 & -0.620 \\
\hline \multirow{2}{*}{ MR } & $\mathrm{PG}$ & 0.003 & 0.00 & -0.002 & 0.000 & 0.000 & 0.003 \\
\hline & PG\% & 0.280 & 0.14 & -0.200 & 0.040 & 0.040 & 0.350 \\
\hline \multirow{2}{*}{ RD\% } & $P G$ & -0.422 & 0.22 & 0.157 & 0.041 & 0.507 & 0.368 \\
\hline & PG\% & -0.530 & 0.28 & 0.200 & 0.050 & 0.640 & 0.470 \\
\hline \multirow{2}{*}{$+b$} & PG & 0.002 & -0.03 & 0.002 & 0.006 & 0.013 & -0.030 \\
\hline & PG\% & 0.020 & -0.31 & 0.020 & 0.080 & 0.150 & -0.360 \\
\hline \multirow{2}{*}{ Total } & $\mathbf{P G}$ & -1.15 & 0.86 & 2.77 & 2.17 & 3.05 & 3.07 \\
\hline & PG\% & 0.92 & 8.19 & 16.39 & 19.07 & 10.12 & 11.51 \\
\hline
\end{tabular}


Table (7): Analysis of variances of the selected breeder seed applications

\begin{tabular}{|c|c|c|c|c|c|c|c|c|c|c|c|c|c|c|}
\hline \multirow{2}{*}{ S.O.V } & \multirow{2}{*}{ d.f. } & \multicolumn{13}{|c|}{ Mean square of the studied traits } \\
\hline & & $\begin{array}{l}S C Y \\
(K / F)\end{array}$ & $\begin{array}{l}\text { LCY } \\
\text { (K/F) }\end{array}$ & $L \%$ & $\mathrm{BW}(\mathrm{g})$ & $\begin{array}{l}\mathrm{SI} \\
(\mathrm{g})\end{array}$ & $\begin{array}{l}\mathrm{LI} \\
(\mathrm{g})\end{array}$ & $\begin{array}{c}2.5 \% \mathrm{SL} \\
(\mathrm{mm})\end{array}$ & UR\% & FS g/tex & $\mathrm{E} \%$ & $\mathrm{MV}$ & $\mathrm{Rd} \%$ & B \\
\hline Breeder & 6 & $55746.0^{* *}$ & $7687.1^{\star \star}$ & 1.09 & 0.02 & $0.42^{* \star}$ & 0.11 & 0.24 & 2.74 & 1.57 & 0.05 & 0.05 & $6.14^{\star \star}$ & 0.23 \\
\hline Rep. & 2 & 137.0 & 38.0 & 0.06 & 0.02 & 0.09 & 0.03 & 0.06 & 0.38 & 1.10 & 0.00 & 0.03 & 0.81 & 0.60 \\
\hline Error & 12 & 160.0 & 63.4 & 0.57 & 0.04 & 0.07 & 0.07 & 0.17 & 1.45 & 1.31 & 0.07 & 0.02 & 1.36 & 0.12 \\
\hline
\end{tabular}

Table (8): Means of the selected breeder seed application

\begin{tabular}{|c|c|c|c|c|c|c|c|c|c|c|c|c|c|}
\hline $\begin{array}{c}\text { Breeder } \\
\text { seed }\end{array}$ & $\begin{array}{c}\text { SCY } \\
(\mathrm{K} / \mathrm{F})\end{array}$ & $\begin{array}{c}\text { LCY } \\
(\mathrm{K} / \mathrm{F})\end{array}$ & $\mathrm{L} \%$ & $\mathrm{BW}(\mathrm{g})$ & $\begin{array}{c}\mathrm{SI} \\
(\mathrm{g})\end{array}$ & $\begin{array}{c}\mathrm{LI} \\
(\mathrm{g})\end{array}$ & $\begin{array}{c}2.5 \% \\
\mathrm{SL} \\
(\mathrm{mm}) .\end{array}$ & UR\% & $\begin{array}{c}\text { FS } \\
(\mathrm{g} / \mathrm{tex})\end{array}$ & E\% & MV & Rd\% & $+\mathrm{b}$ \\
\hline 1 & 8.7 & 9.8 & 35.77 & 3.14 & 10.43 & 5.80 & 34.50 & 85.67 & 48.70 & 6.20 & 3.3 & 75.33 & 7.73 \\
\hline 2 & 11.4 & 13.1 & 36.43 & 3.17 & 9.70 & 5.57 & 33.80 & 85.27 & 49.23 & 6.30 & 3.4 & 75.70 & 8.20 \\
\hline 3 & 10.5 & 12.3 & 37.20 & 3.08 & 9.70 & 5.73 & 33.87 & 86.50 & 49.33 & 6.30 & 3.3 & 77.83 & 8.00 \\
\hline 4 & 10.6 & 12.4 & 37.33 & 3.13 & 10.00 & 5.93 & 34.43 & 87.53 & 48.60 & 6.13 & 3.5 & 77.43 & 8.13 \\
\hline 5 & 7.7 & 9.1 & 37.27 & 3.09 & 9.67 & 5.73 & 34.07 & 86.70 & 48.93 & 6.50 & 3.5 & 79.30 & 7.40 \\
\hline 6 & 7.6 & 8.9 & 37.20 & 3.33 & 10.47 & 6.17 & 34.40 & 87.53 & 47.20 & 6.40 & 3.6 & 77.90 & 7.77 \\
\hline 7 & 6.3 & 7.2 & 36.40 & 3.08 & 10.40 & 5.93 & 34.27 & 87.67 & 48.27 & 6.20 & 3.6 & 78.43 & 7.77 \\
\hline $\begin{array}{c}\text { Mean of } \\
\text { nucleolus }\end{array}$ & 9.0 & 10.4 & 36.80 & 3.15 & 10.05 & 5.84 & 34.19 & 86.70 & 48.61 & 6.29 & 3.46 & 77.42 & 7.86 \\
\hline $\begin{array}{c}\text { Mean of } \\
\text { increase B }\end{array}$ & 6.9 & 7.9 & 36.3 & 2.8 & 11.0 & 6.3 & 34.7 & 86.3 & 47.6 & 6.5 & 3.6 & 78.9 & 8.3 \\
\hline
\end{tabular}

Finally, the main objective of this work was to compare between the independent culling levels method (ICL) and selection index procedures to form the optimum breeder's seed of Giza 92 type in terms of fiber properties and /or high yielding families improved for one or more of three main fiber properties; fineness, strength and length. The basic materials of Giza 92 in year 2015 in the increase B were subject to six applications of selection indexes using all traits, yield traits and fiber traits with three and seven families as selection intensity in each application. To compare the efficiency of all these selection procedures, predicted gains for Application-4 (using yield traits and seven families as selection intensity) was able to increase cotton yield by approximately $8 \%$ however the increasing of fiber traits using Application-5 and Application-6 ranged from 0.35 to $2.31 \%$ these increments could not be considered improvements of these traits because these values in the limits of the Giza 92 type. Several studies indicated that selection index techniques were mostly better than single trait selection.

In conclusion, this work revealed that the independent culling levels method for maintenance and renewing Egyptian cotton varieties is a precise and perfect program to preserve fiber quality. Application of selection index procedure could improve the maintenance of Giza 92 type characteristics for yield and fiber characters. 


\section{REFERENCES}

Abo El-Zahab, A.A., M.A. El-Kilany (1979) Correlated response to several selection procedures for increased lint yield in segregating generations of Egyptian cotton (Gossypium barbadense L). Beitrage trop. Landwirtsch. Veterinarmed. 17. Jg. 165-172.

Ahmad, W., N.U. Khan, M.R. Khalil, A. Parveen, U. Aimen, M. Saeed, Samiullah and S.A. Shah (2008). Genetic variability and correlation analysis in upland cotton. Sarhad J. Agric., 24: 573- 580.

Burton, G.W. (1952). Quantitative inheritance in grasses. Proc. 6th Internat. Grassland Congr. 1: 277-283.

Dewey, D.R. and K.H. Lu (1959). A correlation and path coefficient analysis of components of crested wheat grass seed production. Agron. J. 51(9): 515-518.

Dhivya, R., P. Amalabalu, R. Pushpa and D. Kavithamani (2014). Variability, heritability and genetic advance in upland cotton (Gossypium hirsutum L.). Afr. J. Plant Sci., 8(1): 1-5.

El-Kilany, M.A. (1976) Comparative studies of selection techniques in maintaining Egyptian cotton. Ph.D. Thesis, Cairo Univ., Egypt.

El-Lawendey, M.M. and M.A.A. El-Dahan (2012).Comparison between direct and indirect selection and two indices in segregating population of cotton. J. Agric. Res. Kafr El-Sheikh Univ. 38(1):3753.

El-Lawendey, M.M.; Y.A. Soliman; A.R. Abd El-Bary and Y.M. El-Mansy (2008). Using fourteen selection procedures to evaluate predicted and realized genetic gain in cotton cross G.86 x Suvin. Egypt. J. Plant Breed, 12(1): 157-175.

El-Lawendey, M.M.; Y.M. El-Mansy and M.A.A.El-Dahan (2011). Economic values effects on genetic gains of lint yield and its components using selection indices. Minufiya J. Agric. Res., 36(6): 1549-1668.

Hair, J.F.; Jr. R.E. Anderson and R.L. Tatham (1987). Multivariate Data Analysis with Reading. MacMillan Publ., Co., New York.

Hazel, L.N. (1943). The genetics basis for constructing selection indices. Genetics, 28: 476-490.

Kaiser, H. F. (1958) The varimax criterion for analytic rotation in factor analysis. Psychometrika 23, 187-200.

Kapoor, G.J. and S.K. Kasushik (2003). Variability, heritability and genetic advance studies in cotton. J. Cotton Res. Dev.17: 240-241.

Khan, N.U. (2003). Genetic analysis, combining ability and heterotic studies for yield, its components, fibre and oil quality traits in upland cotton (G. hirsutum). Ph.D. Dissertation, Sindh Agric. Univ. Tandojam, Pakistan.

Khan, N.U., G. Hassan, M.B. Kumbhar, A. Parveen, U. Aiman, W. Ahmad, S.A. Shah and S. Ahmad (2007). Gene action of seed traits and oil content in upland cotton (G. hirsutum). Sabrao J. Breed. \& Genet., 39: 17-30.

Larik, A.S., S.I. Malik, A.A. Kakar and M.A. Naz (2000). Assessment of heritability and genetic advance for yield components in $G$. hirsutum. Scient. Khyber. 13: 39-44. 
Larik, A.S., S.R. Ansari and M.B. Kumbhar (1997). Heritability analysis of yield and quality components in G. hirsutum. Pak. J. Bot. 29: 97101.

Manning, H.L. (1956) Yield improvement from a selection index technique with cotton. Heredity, 10:303-322.

Meena, R.A., M.N. Mishra and R.G. Dani (2001). Genetic variability and correlation for seed-quality parameters in upland cotton (Gossypium hirsutum L.). Indian J. Agric. Sci. 71(6): 417-420.

Miller, P.A., J.C. Williams, H.F. Robinson and R.E. Comstock (1958). Estimates of genotypic and environmental variances and covariances in upland cotton and their implications in selection. Agron. J. 50:126-131

Pesek, J. and J. Baker (1970). An application of index selection to the improvement of self pollinated species. Can. J. Platrt Sci, 50: 267276.

Ramadan, B.M.; Y.M. El-Mansy; M.A. Al-Ameer; M.A. Abou El-Yazied (2014). Improvement of some economic characters through direct selection in Egyptian cotton . Egypt. J. Plant Breed. 18(4):783-797.

Smith, H.F. (1936) A discriminant function for plant selection. Ann. Eugen., 7:240-250.

Srour, M.S.M., M.A. Hager, E.I. Zaazaa, E.F.EL-Hashash (2010) Genetic analysis for some yield and fiber quality traits using F2 and F3 populations in Cotton. J. Plant Prod. Mansoura Univ. 1(12):15931604.

Soomro, Z.A., A.S. Larik, M.B. Kumbhar, N.U. Khan and N.A. Panhwar (2008). Correlation and path analysis in hybrid cotton. Sabrao J. Breed. \& Genet., 40: 49-56.

SPSS (1995). SPSS Computer User's Guide SPSS in USA.

Vencovsky, R. (1969). Genética quantitativa. In: Kerr WE (ed.) Melhoramento e genética. Melhoramento, São Paulo, p.17-38.

Walker, J.T. (1960). The use of a selection index technique in the analysis of progeny row data. Emp. Cott. Gr. Rev. 37: 81-107.

$$
\begin{aligned}
& \text { مقارنة بين بعض طرق الإنتخاب لإنتاج نويـة (بذرة العربية المربي) صنف القطن } \\
& \text { المصري جيزة } \\
& \text { محمد أحمد عاشور الاهان } \\
& \text { معهد بحوث القطن - مركز البحوث الزراعية ــ مصر الثمان }
\end{aligned}
$$

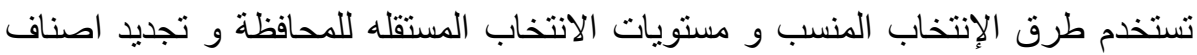

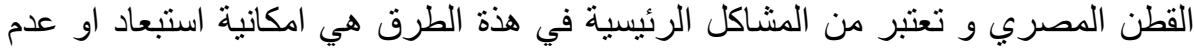

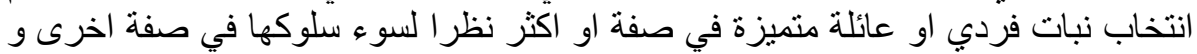

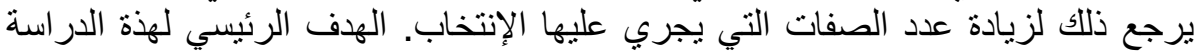

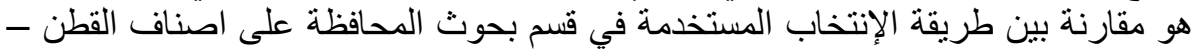


معهد بحوث القطن - مركز البحوث الزر اعية للمحافظة و تجديد بذرة المربي للصنف جيزة

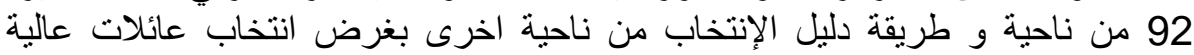

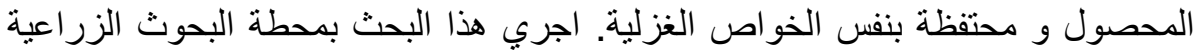

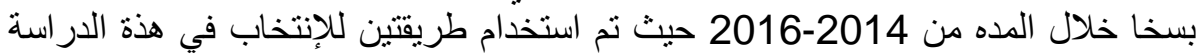

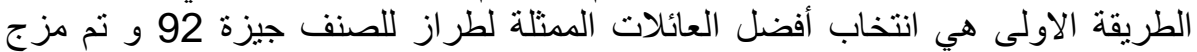

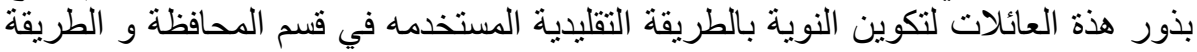

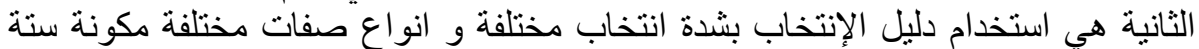

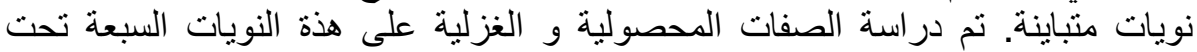

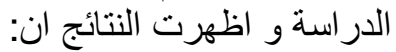

1. اظهرت قيم المتوسطات عدم وجود اختلاف كبير بين متوسط العائلات المنتخبة و

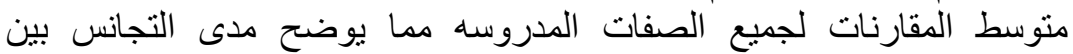

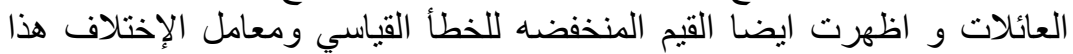

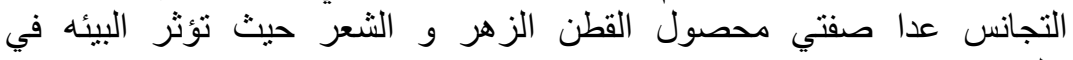
سلوكيهما.

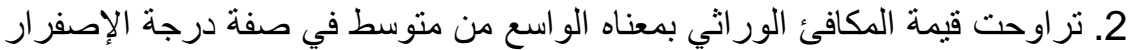

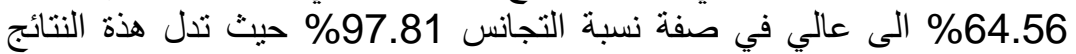
على إمكانية المحافظة على الصفات القياسية للصنف جيزة 92 بمجرد الإنتخاب لهذة الصفات. الصكانة الصفات

3. اظهر التحليل العاملي ان اول و اهم ثثلاثة عو امل شكلت

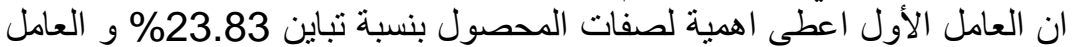

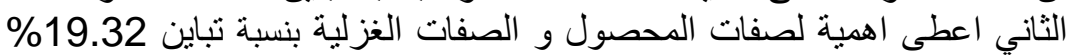

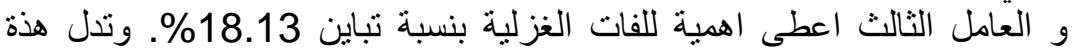

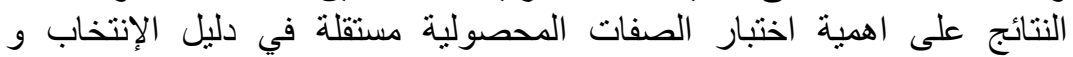

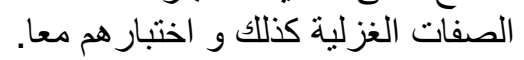

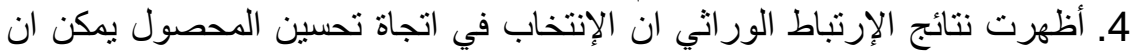

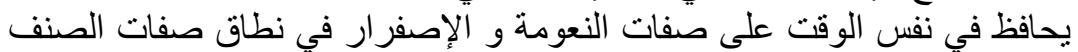

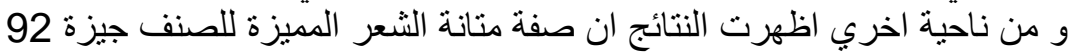

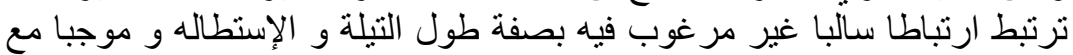

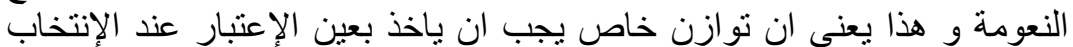
لهذة الصفات. 5. بينت نتائج التحسين الوراثي المتوقع لاليل الإنتخاب للتطبيقات السته ان التطبيف

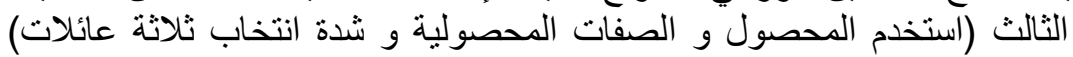

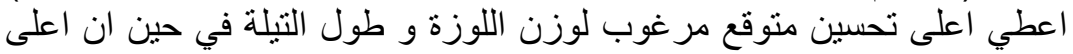

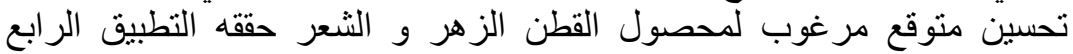

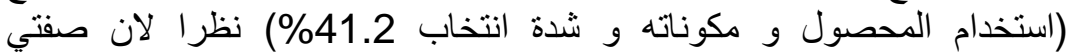

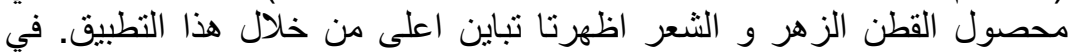

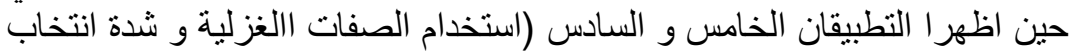

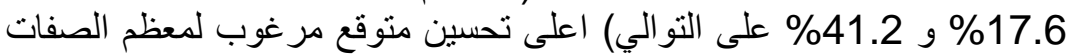


6. اظهر تحليل التباين للنويات المختلفة (الناتجة من طريقة القسم و طرق دليل

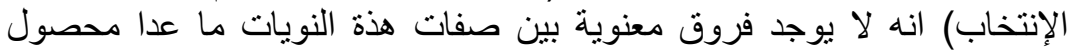

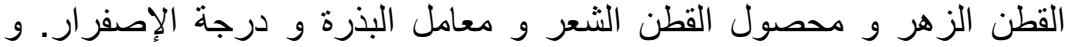

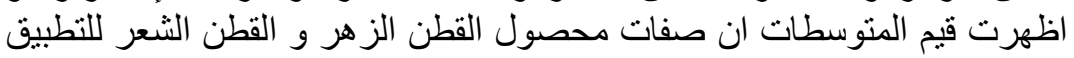

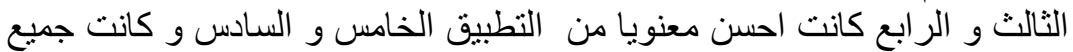

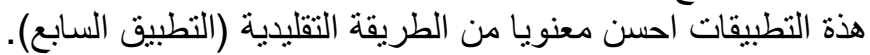

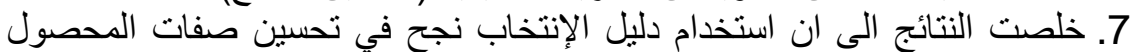

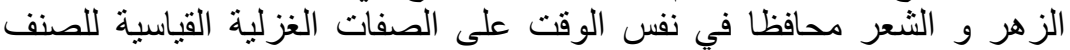

